\title{
Effects of multiple-dose ponesimod, a selective $S I P$, receptor modulator, on lymphocyte subsets in healthy humans
}

This article was published in the following Dove Press journal:

Drug Design, Development and Therapy

28 December 2016

Number of times this article has been viewed

\author{
Stipo Jurcevic' \\ Pierre-Eric Juif ${ }^{2}$ \\ Colleen Hamid ${ }^{3}$ \\ Roseanna Greenlaw ${ }^{3}$ \\ Daniele D'Ambrosio \\ Jasper Dingemanse ${ }^{2}$ \\ 'Department of Biomedical \\ Sciences, University of Westminster, \\ London, UK; ' ${ }^{2}$ Department of \\ Clinical Pharmacology, Actelion \\ Pharmaceuticals Ltd, Allschwil, \\ Switzerland; ${ }^{3}$ Division of \\ Transplantation Immunology \& \\ Mucosal Biology, King's College \\ London, London, UK
}

\begin{abstract}
This study investigated the effects of ponesimod, a selective $\mathrm{S}_{1} \mathrm{P}_{1}$ receptor modulator, on $\mathrm{T}$ lymphocyte subsets in 16 healthy subjects. Lymphocyte subset proportions and absolute numbers were determined at baseline and on Day 10, after once-daily administration of ponesimod (10 mg, $20 \mathrm{mg}$, and $40 \mathrm{mg}$ each consecutively for 3 days) or placebo (ratio 3:1). The overall change from baseline in lymphocyte count was $-1,292 \pm 340 \times 10^{6}$ cells/ $\mathrm{L}$ and $275 \pm 486 \times 10^{6}$ cells/L in ponesimod- and placebo-treated subjects, respectively. This included a decrease in both $\mathrm{T}$ and $\mathrm{B}$ lymphocytes following ponesimod treatment. A decrease in naïve $\mathrm{CD} 4^{+} \mathrm{T}$ cells $\left(\mathrm{CD} 45 \mathrm{RA}^{+} \mathrm{CCR} 7^{+}\right)$from baseline was observed only after ponesimod treatment $\left(-113 \pm 98 \times 10^{6}\right.$ cells $/ \mathrm{L}$, placebo: $0 \pm 18 \times 10^{6}$ cells $\left./ \mathrm{L}\right)$. The number of T-cytotoxic $\left(\mathrm{CD} 3^{+} \mathrm{CD} 8^{+}\right)$ and $\mathrm{T}$-helper $\left(\mathrm{CD}^{+}{ }^{+} \mathrm{CD} 4^{+}\right)$cells was significantly altered following ponesimod treatment compared with placebo. Furthermore, ponesimod treatment resulted in marked decreases in $\mathrm{CD}^{+} \mathrm{T}$-central memory $\left(\mathrm{CD} 45 \mathrm{RA}^{-} \mathrm{CCR} 7^{+}\right)$cells $\left(-437 \pm 164 \times 10^{6}\right.$ cells/L) and CD4 ${ }^{+} \mathrm{T}$-effector memory $\left(\mathrm{CD}^{2} 5 \mathrm{RA}^{-} \mathrm{CCR} 7^{-}\right)$cells $\left(-131 \pm 57 \times 10^{6}\right.$ cells $\left./ \mathrm{L}\right)$. In addition, ponesimod treatment led to a decrease of $-228 \pm 90 \times 10^{6}$ cells/L of gut-homing T cells $\left(\mathrm{CLA}^{-}\right.$integrin $\left.\beta 7^{+}\right)$. In contrast, when compared with placebo, $\mathrm{CD} 8^{+} \mathrm{T}$-effector memory and natural killer $(\mathrm{NK})$ cells were not significantly reduced following multiple-dose administration of ponesimod. In summary, ponesimod treatment led to a marked reduction in overall $\mathrm{T}$ and $\mathrm{B}$ cells. Further investigations revealed that the number of $\mathrm{CD} 4^{+}$cells was dramatically reduced, whereas $\mathrm{CD} 8^{+}$and $\mathrm{NK}$ cells were less affected, allowing the body to preserve critical viral-clearing functions.
\end{abstract}

Keywords: ponesimod, multiple dose, $\mathrm{S} 1 \mathrm{P}_{1}$ receptor, lymphocyte subsets, CD45RA/CCR7

\section{Introduction}

The adaptive immune system is responsible for maintaining immune competence, and it relies on the constant circulation of lymphocytes between lymphoid organs and other tissues in the body. In order to fulfill their function as surveyors of cognate antigen, mature lymphocytes leave the thymus and bone marrow to enter the circulation and lymphatic system and reach secondary lymphoid organs. ${ }^{1}$ Lysophospholipid sphingosine-1-phosphate $(\mathrm{S} 1 \mathrm{P})$, via the $\mathrm{S}_{1} \mathrm{P}_{1}$ receptor, has been shown to play a central role in the transit or egress of $\mathrm{T}$ lymphocytes out of the thymus as well as their movement between blood, lymphatics, and non-lymphoid tissues. ${ }^{2-5} \mathrm{~S}_{1} \mathrm{P}_{1}$ receptor modulators bind to the receptor resulting in its internalization, degradation, and downregulation (ie, functional antagonism). In this way, lymphocytes cannot respond to the S1P signal in the blood and remain in the secondary lymphoid system and the thymus. ${ }^{6}$ This mechanism was foreseen as a possible therapeutic strategy in order to divert lymphocytes from sites of inflammation. Lymphocytes return to the blood and lymphatic
Correspondence: Pierre-Eric Juif Department of Clinical Pharmacology, Actelion Pharmaceuticals Ltd, Gewerbestrasse 16, CH-4I23

Allschwil, Switzerland

$\mathrm{Tel}+4 \mathrm{I} 6 \mathrm{I} 5658890$

$\mathrm{Fax}+4 \mid$ 6I 5656200

Email pierre-eric.juif@actelion.com
Drug Design, Development and Therapy 2017:|| |23-13|

(c) (1) (8) ๑ 2017 Jurcevic et al. This work is published and licensed by Dove Medical Press Limited. The full terms of this license are available at https:/wwww.dovepress.com/terms.php cc. hereby accept the Terms. Non-commercial uses of the work are permitted without any further permission from Dove Medical Press Limited, provided the work is properly attributed. For permision for commercial use of this work, please see paragraphs 4.2 and 5 of our Terms (https://www.doveppess. com/terms.php). 
circulation from their sites of sequestration following withdrawal of an $\mathrm{S}_{1} \mathrm{P}_{1}$ receptor modulator. ${ }^{3}$ On this basis, selective (eg, ponesimod) and non-selective (eg, fingolimod $\left[\right.$ Gilenya ${ }^{\circledR}$ ]) $\mathrm{S}_{1} \mathrm{P}_{1}$ receptor modulators have been developed for the treatment of autoimmune diseases such as multiple sclerosis (MS). ${ }^{7-9}$ These immunomodulators affect different subpopulations of lymphocytes. ${ }^{10,11}$ In this study, we have extended the investigation of the lymphocyte subsets to include T-central memory (TCM) and T-effector memory (TEM) subpopulations. These subpopulations are defined by the expression of surface markers CD45RA and CCR7. ${ }^{12}$ As TCM and TEM cells and their $\mathrm{CD}^{+}$(helper T cells) and $\mathrm{CD}^{+}$(cytotoxic $\mathrm{T}$ cells) subtypes are thought to play distinct roles in immunopathology and protection against viral infections, the effects of multiple-dose treatment with ponesimod on these $\mathrm{T}$ cell subsets could elucidate the therapeutic mechanisms associated with selective $\mathrm{S}_{1} \mathrm{P}_{1}$ receptor modulation.

\section{Methods}

\section{Subjects and study design}

The details (ie, inclusion and exclusion criteria, study design, and demographics) of this double-blind, placebo-controlled, parallel-group, randomized, up-titration study have been previously described. ${ }^{13}$ Briefly, 16 subjects received either ponesimod or placebo (ratio 3:1) with an up-titration scheme from $10 \mathrm{mg}$ to $100 \mathrm{mg}$. The up-titration scheme was used since in previous studies this was found to diminish the effects on heart rate observed with administration of ponesimod. ${ }^{14,15}$

Subjects were administered the following ascending doses of ponesimod/placebo for 3 days each: $10 \mathrm{mg}, 20 \mathrm{mg}, 40 \mathrm{mg}$, $60 \mathrm{mg}, 80 \mathrm{mg}$, and $100 \mathrm{mg}$. The study drug was administered once daily (o.d.) in the morning (fasted conditions) for a total of 18 days. Written informed consent was obtained from all individual participants included in the study.

\section{Flow cytometry analysis}

On Day 1 pre-dose (baseline) and on Day 10 (prior to the first administration of $60 \mathrm{mg}$ ponesimod), $1.5 \mathrm{~mL}$ of blood was collected into ethylene diamine tetraacetic acid (EDTA) tubes and analyzed within 24 hours for lymphocyte subsets using four-color flow cytometry. The number of circulating $\mathrm{T}$ lymphocytes $\left(\mathrm{CD}^{+}\right)$, helper $\mathrm{T}$ cells $\left(\mathrm{CD}^{+} \mathrm{CD}^{+}\right)$, cytotoxic $\mathrm{T}$ cells $\left(\mathrm{CD} 3^{+} \mathrm{CD}^{+}\right)$, TCM cells $\left(\mathrm{CD}^{2} 5 \mathrm{RA}^{-} \mathrm{CCR} 7^{+}\right)$, TEM cells $\left(\mathrm{CD}^{2} 5 \mathrm{RA}^{-} \mathrm{CCR}^{-}\right)$, effector $\mathrm{T}$ cells $\left(\mathrm{CD}^{2} 5 \mathrm{RA}^{+} \mathrm{CCR}^{-}\right)$, natural killer $(\mathrm{NK})$ cells $\left(\mathrm{CD}^{-}{ }^{-} \mathrm{CD} 56^{+}\right)$, natural killer $\mathrm{T}(\mathrm{NKT})$ cells $\left(\mathrm{CD}^{+}{ }^{+} \mathrm{CD} 56^{+}\right)$, regulatory $\mathrm{T}$ cells $\left(\mathrm{CD} 25^{+} \mathrm{FoxP}^{+}\right)$, and $\mathrm{B}$ cells $\left(\mathrm{CD} 19^{+}\right)$was determined using flow cytometry. Monoclonal antibodies for specific cell markers were conjugated to fluorescein isothiocyanate (FITC), phycoerythrin (PE), allophycocyanin (APC), or peridinin chlorophyll protein (PerCP). More specifically, CD3-APC/CD4-PE/CD45RA-FITC/CCR7phycoerythrin-cyanine dye (PECy7) antibodies were used to determine percent $(\%)$ of $\mathrm{CD}^{+} \mathrm{CD}^{+} \mathrm{CD} 45 \mathrm{RA}^{ \pm} \mathrm{CCR} 7^{ \pm}$ cells, CD3-APC/CD8-PE/CD45RA-FITC/CCR7$\mathrm{PECy} 7$ to determine $\%$ of $\mathrm{CD}^{+} \mathrm{CD}^{+} \mathrm{CD}^{2} 5 \mathrm{RA}^{ \pm} \mathrm{CCR}^{ \pm}$ cells, CD45-PE/CD3-APC/CD19-FITC to determine $\%$ of $\mathrm{CD}^{+}$and $\mathrm{CD}^{-}{ }^{-\mathrm{CD} 19^{+}}$cells, CD45-PE/CD3-APC/ CD56-AlexaFluor488 to determine $\%$ of $\mathrm{CD} 3{ }^{ \pm} \mathrm{CD}^{2} 6^{+}$ cells, CD4-FITC/CD25-PE/Foxp3-APC to determine $\%$ of $\mathrm{CD}^{+}{ }^{+} \mathrm{CD} 25^{+} \mathrm{Foxp}^{+}$cells, and $\mathrm{CD} 3-\mathrm{APC} / \mathrm{CD} 4-\mathrm{PECy} 7 /$ CLA-FITC integrin to determine $\%$ of gut-homing $\mathrm{T}$ cells $\left(\mathrm{CLA}^{-}\right.$integrin $\left.\beta 7^{+}\right)$and skin-homing T cells $\left(\mathrm{CLA}^{+}\right.$integrin $\beta 7^{-}$). Antibodies were purchased from BD Biosciences (San Jose, CA, USA), eBioscience (San Diego, CA, USA), and Insight Biotechnology (Middlesex, UK). Cells were analyzed using the Dako Cyan flow cytometer and Summit software. The instrument was calibrated using FluoroSpheres calibration beads (Dako, Glostrup, Denmark), and set-up tubes incorporating each individual antibody and unstained cells were run before each set of samples was analyzed in order to eliminate spectral overlap. The gating was determined using distinct forward and side scatter properties of the lymphocyte population. Furthermore, the gating was confirmed by staining with a lymphocyte-specific antibody CD3. The isotype controls for antibody staining were analyzed during the assay validation procedure.

\section{Statistical methods}

Absolute count (expressed as number of cells/L) and percentage change from baseline in lymphocyte count are presented as mean ( \pm standard deviation [SD]). Statistical analysis was performed using GraphPad Prism 6 (GraphPad Software, La Jolla, CA, USA). Lymphocyte counts were compared by treatment group using one-way analysis of variance (ANOVA) and Bonferroni's multiple comparison test. A $P$-value of $<0.05$ was considered as statistically significant.

\section{Ethical approval}

All procedures performed in studies involving human participants were in accordance with the ethical standards of the institutional and/or national research committee and with the 1964 Declaration of Helsinki and its later amendments or comparable ethical standards. The study was approved by Wandsworth Research Ethics Committee. 


\section{Results}

\section{Effects on $T$ and $B$ lymphocytes}

The overall mean lymphocyte count showed a marked decrease from baseline in ponesimod-treated subjects. ${ }^{13}$ At baseline, the mean $( \pm \mathrm{SD})$ lymphocyte count was $1,908 \pm 387 \times 10^{6}$ cells $/ \mathrm{L}$ and $1,825 \pm 287 \times 10^{6}$ cells $/ \mathrm{L}$ in the ponesimod and placebo groups, respectively. On Day 10 before administration of the first dose of $60 \mathrm{mg}$ ponesimod, the mean total lymphocyte count was $617 \pm 112 \times 10^{6}$ cells $/ \mathrm{L}$ in ponesimod-treated subjects $(P<0.001$ vs baseline), whereas an increase was observed in placebo-treated subjects to reach $2,100 \pm 258 \times 10^{6}$ cells $/ \mathrm{L}(P>0.05$ vs baseline; $P<0.001$ placebo vs ponesimod on Day 10). The percentage change from baseline is depicted in Figure 1A.

A minimum mean lymphocyte count of $400 \times 10^{6}$ cells $/ \mathrm{L}$ was reached on Day 10, 4 hours after the subjects received their first daily dose of $60 \mathrm{mg}$ ponesimod. ${ }^{13}$ The mean count did not decrease further during the study with up-titration of the ponesimod dose to $80 \mathrm{mg}$ and $100 \mathrm{mg}$ daily. Importantly, the mean lymphocyte count was quickly reversible upon discontinuation of ponesimod; by Day 29 (10 days after discontinuation of treatment), the mean lymphocyte count was $1,600 \pm 228 \times 10^{6}$ cells/ $\mathrm{L}$ compared to a mean baseline count of $1,908 \pm 387 \times 10^{6}$ cells $/ \mathrm{L}$.

Both $\mathrm{T}\left(\mathrm{CD}^{+}\right)$and $\mathrm{B}\left(\mathrm{CD}^{-}{ }^{-} \mathrm{CD} 19^{+}\right)$lymphocytes were affected by ponesimod treatment. The flow cytometry analysis results of the $\mathrm{T}$ and $\mathrm{B}$ cell subsets from a representative ponesimod-treated subject are shown in Figure S1.

In placebo-treated subjects, an increase in the mean count of $T$ cells was observed (from $1,273 \pm 269 \times 10^{6}$ cells/L to $1,507 \pm 139 \times 10^{6}$ cells/L), whereas a significant decrease (from
$1,399 \pm 311 \times 10^{6}$ cells $/ \mathrm{L}$ to $334 \pm 86 \times 10^{6}$ cells $/ \mathrm{L} ; P<0.001$; Figure 1B) was detected in ponesimod-treated subjects. Whereas the mean count of B cells $\left(\mathrm{CD}^{-} \mathrm{CD} 19^{+}\right)$slightly increased in the placebo group between Day $1\left(186 \pm 49 \times 10^{6}\right.$ cells/L) and Day $10\left(234 \pm 65 \times 10^{6}\right.$ cells/L), a significant decrease was observed in ponesimod-treated subjects (from $215 \pm 63 \times 10^{6}$ cells/L to $46 \pm 18 \times 10^{6}$ cells $/ \mathrm{L} ; P<0.001$; Figure 1E).

The analysis of the $\mathrm{T}$ cell subsets in ponesimod-treated subjects showed marked decreases in the mean count of helper $\left(\mathrm{CD}^{+} \mathrm{CD}^{+}\right)$and cytotoxic $\left(\mathrm{CD}^{+} \mathrm{CD}^{+}\right) \mathrm{T}$ cells. Helper and cytotoxic $\mathrm{T}$ cells increased from $687 \pm 110 \times 10^{6}$ cells $/ \mathrm{L}$ to $848 \pm 46 \times 10^{6}$ cells/L and from $476 \pm 167 \times 10^{6}$ cells/L to $554 \pm 135 \times 10^{6}$ cells/L, respectively, in the placebo group. In the ponesimod group, a significant decrease from $801 \pm 222 \times 10^{6}$ cells $/ \mathrm{L}$ to $115 \pm 47 \times 10^{6} \mathrm{cells} / \mathrm{L}(P<0.001$ Day 10 vs baseline; $P<0.001$ placebo vs ponesimod) and from $484 \pm 117 \times 10^{6}$ cells $/ \mathrm{L}$ to $172 \pm 45 \times 10^{6}$ cells $/ \mathrm{L}(P<0.001$ Day 10 vs baseline; $P<0.001$ placebo vs ponesimod) was observed for helper $\left(\mathrm{CD}^{+} \mathrm{CD}^{+}\right)$and cytotoxic $\left(\mathrm{CD}^{+} \mathrm{CD}^{+}\right)$ $\mathrm{T}$ cells, respectively. Percentage change from baseline is represented in Figure $1 \mathrm{C}$ and $\mathrm{D}$.

\section{Effects on $\mathrm{CD}^{+} \mathrm{T}$ cell subpopulations}

The effects of ponesimod on the subpopulations of $\mathrm{CD}^{+}$ T-helper cells were further analyzed by using CD45RA and CCR7 surface markers. The flow cytometry analysis of a representative ponesimod-treated subject is shown in Figure 2. The initial lymphocyte gate (graph not shown) was followed by gating on $\mathrm{CD}^{+} \mathrm{CD}^{+}{ }^{+} \mathrm{T}$ cells (Figure $2 \mathrm{~A}$ and $\mathrm{C}$, gate R6). The gated $\mathrm{CD}^{+} \mathrm{CD}^{+} \mathrm{T}$ cells were further analyzed
A

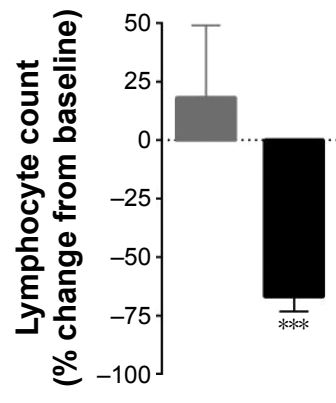

Total count
B

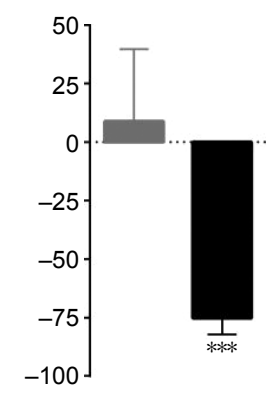

T cells
C

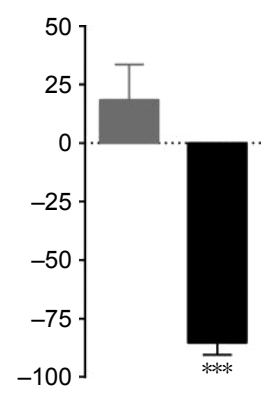

T-helper
D

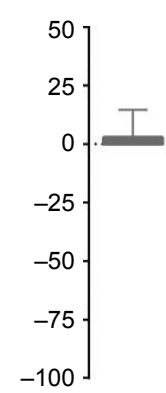

T-cytotoxic
E

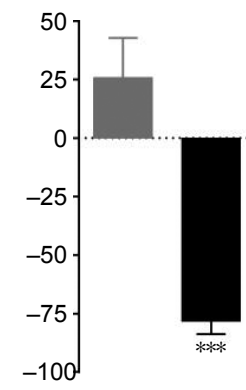

B cells

Figure I Effect of placebo and ponesimod on total T and B cells count.

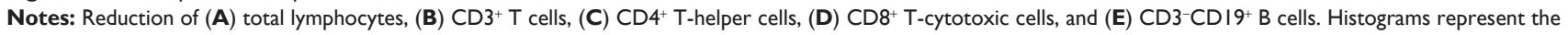
mean and SD of the percentage change from baseline (ie, Day I pre-dose) after 9 days of treatment with either placebo (gray bars) or ponesimod (black bars). Significance code: $* * * P<0.00$ I Student's $t$-test placebo vs ponesimod.

Abbreviation: SD, standard deviation. 
A

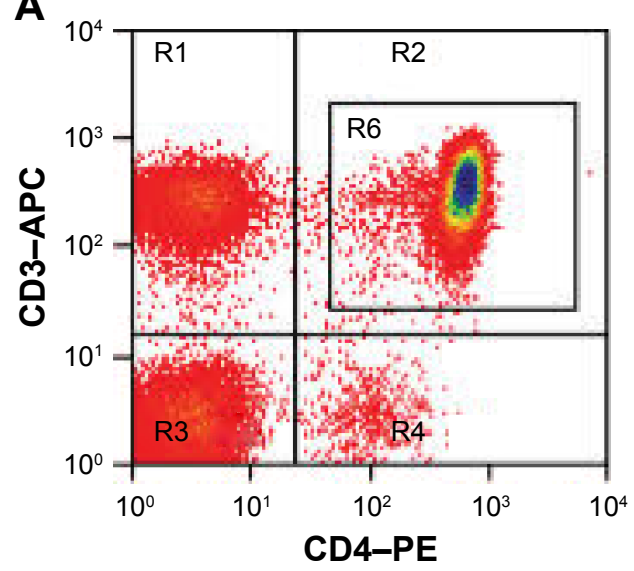

C

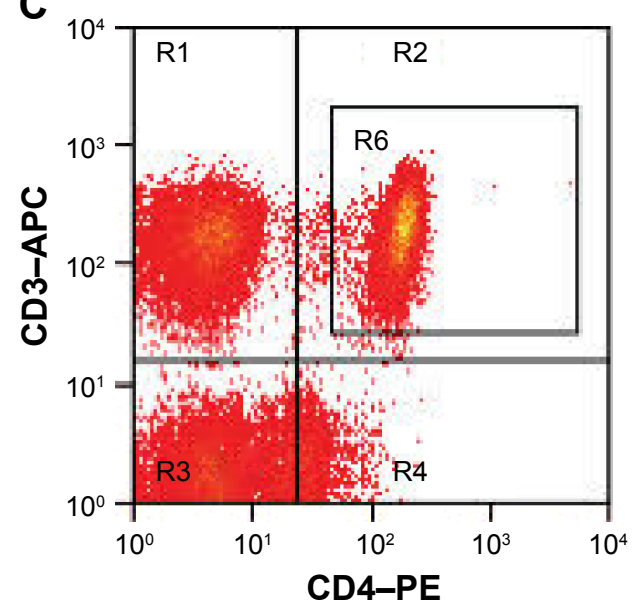

B

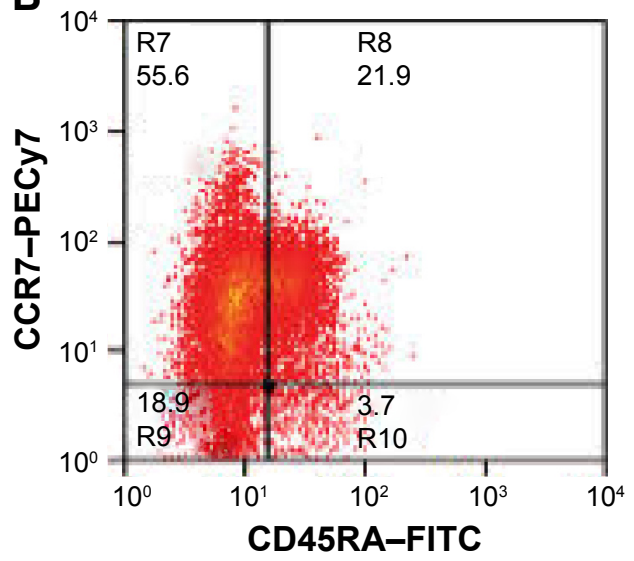

D

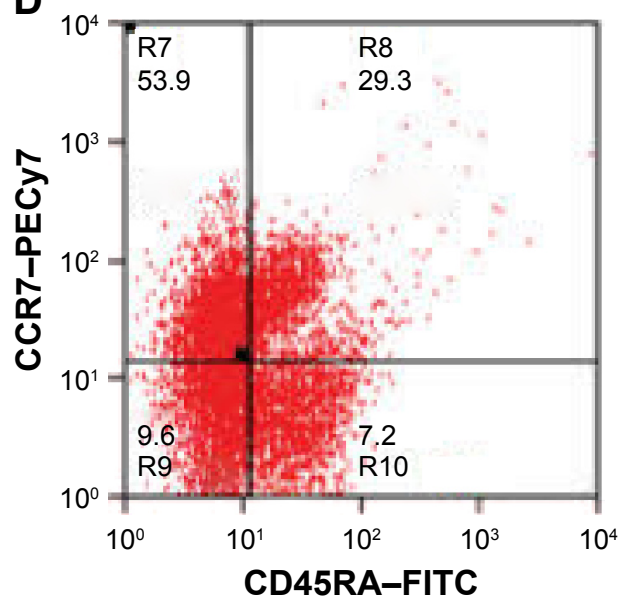

Figure 2 Flow cytometric analysis of $\mathrm{CD}^{+} \mathrm{CD}^{+}$helper T cells expressing CD45RA and CCR7.

Notes: (A) The $C D 3^{+} C D 4^{+} T$ cells at baseline (Day I) are gated (R6) and further analyzed for the expression of (B) CD45RA and CCR7 (R8 and RI0). The same subject is analyzed after ponesimod treatment on Day 10. (C) The CD3 ${ }^{+} C D 4^{+} T$ cells are gated (R6) and further analyzed for the expression of (D) CD45RA and CCR7. The relative decrease of $\mathrm{T}$ effector memory cells (percentage of CD45RA-/CCR7- cells counted in gate R6) is shown in the lower left quadrant (9.6\% on Day I0 vs $18.9 \%$ at Day I baseline). In contrast, effector T cells (percentage of CD45RA ${ }^{+} C C R 7^{-}$cells counted in gate R6), lower right quadrant, show a relative increase on Day 10 (7.2\% vs $3.7 \%$ at baseline). The increased number of cells in dot plots is reflected in the change in color from red to yellow, followed by green and blue for the highest number of cells.

Abbreviations: APC, allophycocyanin; PE, phycoerythrin; FITC, fluorescein isothiocyanate.

for the expression of CD45RA (x axis) and CCR7 (y axis), as shown in Figure 2B and D. The relative decrease in the proportion of TEM cells (CD45RA- $\mathrm{CCR}^{-}$) was prominent on flow cytometry graphs (Figure $2 \mathrm{~B}$ and D), ie, from $18.9 \%$ at baseline to $9.6 \%$ on Day 10 . In contrast, effector T cells $\left(\mathrm{CD}^{2} 5 \mathrm{RA}^{+} \mathrm{CCR}^{-}\right)$showed a relative proportional increase on Day $10(7.2 \%)$ when compared to baseline $(3.7 \%)$ (Figure 2B and D).

The relative changes in the proportion of $\mathrm{T}$ cell subsets were used to calculate absolute cell numbers based on the measurements of lymphocyte counts and appropriate flow cytometry gating. As shown in Figure 3A, the mean number of naïve $\mathrm{CD}^{+} \mathrm{T}$ cells $\left(\mathrm{CD} 45 \mathrm{RA}^{+} \mathrm{CCR} 7^{+}\right)$remained stable following placebo administration but fell sharply (from $143 \pm 121 \times 10^{6}$ cells $/ \mathrm{L}$ to $12 \pm 12 \times 10^{6}$ cells/L; $P<0.05$ vs baseline; $P<0.05$ placebo vs ponesimod) after o.d. administration of ponesimod for 10 days. No significant change in the absolute number of effector $\mathrm{CD}^{+} \mathrm{T}$ cells was observed. This corresponds to the changes in relative proportion of these cells in flow cytometry graphs (Figure 2B and D); however, this might be related to the high variability observed at baseline in the ponesimod group. Mean percentage change from baseline revealed a slight difference between both groups $(P>0.05$; Figure $3 \mathrm{~B})$. In the placebo group, $\mathrm{CD}^{+}$ TCM (CD45RA $\left.{ }^{-} \mathrm{CCR} 7^{+}\right)$and $\mathrm{CD}^{+}$TEM cells remained stable between Day 1 (TCM: $463 \pm 60 \times 10^{6}$ cells/L; TEM: $118 \pm 57 \times 10^{6}$ cells/L) and Day 10 (TCM: $596 \pm 147 \times 10^{6}$ cells/L; TEM: $119 \pm 48 \times 10^{6}$ cells/L). Following treatment with ponesimod, CD4 ${ }^{+}$TCM and TEM cells significantly fell from $492 \pm 175 \times 10^{6}$ cells $/$ L to $70 \pm 34 \times 10^{6}$ cells $/ L(P<0.001$ Day 1 vs Day 10 and $P<0.001$ placebo vs ponesimod) and from $157 \pm 57 \times 10^{6}$ cells $/ \mathrm{L}$ to $31 \pm 16 \times 10^{6}$ cells $/ \mathrm{L}(P<0.001$ Day 1 


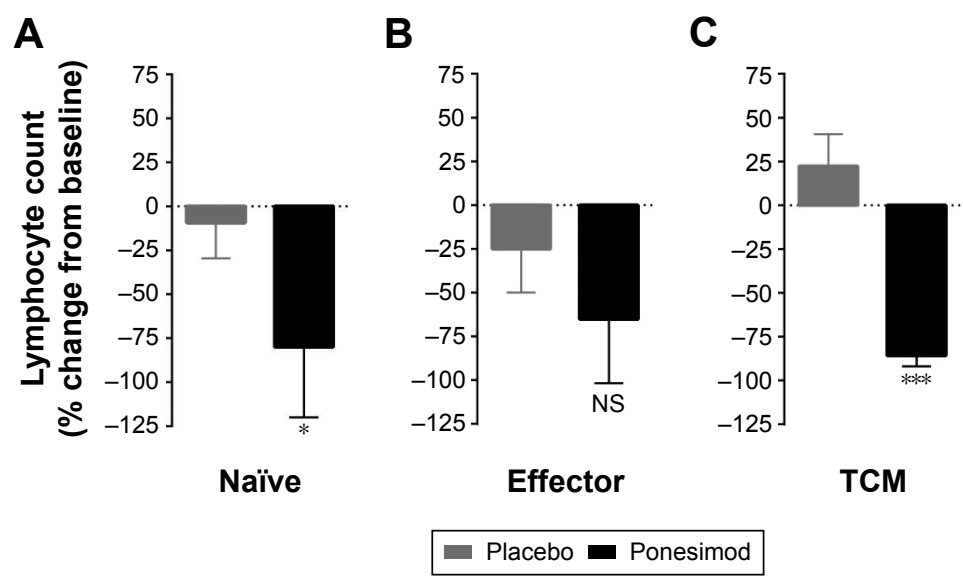

D

Notes: Percentage change from baseline (Day I pre-dose) in (A) peripheral blood naïve (CD45RA $\left.{ }^{+} C C R 7^{+}\right),(B)$ effector $\left(C D 45 R A^{+} C C R 7^{-}\right),(\mathbf{C})$ TCM $\left(C D 45 R A{ }^{-} C C R 7^{+}\right)$, and (D) TEM (CD45RA $\left.{ }^{-} C C R 7^{-}\right) C D^{+} T$ cells on Day 10 post-dose with placebo or ponesimod. Data are presented as mean with $S D$. Significance code: $* P<0.05$, $* * * P<0.00$ I; $t$-test placebo vs ponesimod.

Abbreviations: TCM, T-central memory; TEM, T-effector memory; SD, standard deviation; NS, not significant.

vs Day 10 and $P<0.001$ placebo vs ponesimod), respectively (Figure $3 \mathrm{C}$ and $\mathrm{D}$ ).

\section{Effects on $\mathrm{CD}^{+} \mathrm{T}$ cell subpopulations}

The cytotoxic $\mathrm{CD} 8^{+} \mathrm{T}$ cell subpopulations were also further analyzed using surface expression of CD45RA and CCR7 markers. A similar baseline for the placebo $\left(190 \pm 92 \times 10^{6}\right.$ cells/L) and ponesimod $\left(188 \pm 99 \times 10^{6}\right.$ cells/L) groups was observed for the mean number of circulating naïve $\mathrm{CD} 8^{+}$ cells. A slight increase was observed in the placebo group on Day $10\left(235 \pm 78 \times 10^{6}\right.$ cells $\left./ \mathrm{L}\right)$, whereas a significant decrease was observed $\left(12 \pm 5 \times 10^{6}\right.$ cells/L on Day $10 ; P<0.0001$; Figure 4A) in the ponesimod group. Despite a small decrease in the number of $\mathrm{CD} 8^{+}$effector $\mathrm{T}$ cells in the placebo group (from $64 \pm 27 \times 10^{6}$ cells $/ \mathrm{L}$ to $50 \pm 17 \times 10^{6}$ cells/L), a significant drop was observed in ponesimod-treated subjects (from $113 \pm 69 \times 10^{6} \mathrm{cells} / \mathrm{L}$ to $54 \pm 24 \times 10^{6}$ cells $/ \mathrm{L} ; P<0.05$; Figure 4B). Ponesimod led to a significant decrease in CD8 ${ }^{+}$TCM cells count (Day 1: $32 \pm 17 \times 10^{6}$ cells/L, Day 10: $8 \pm 4 \times 10^{6}$ cells $/ \mathrm{L} ; P<0.01$ ), whereas this count was not affected by placebo treatment (Day 1: $50 \pm 25 \times 10^{6}$ cells $/ \mathrm{L}$, Day 10: $63 \pm 29 \times 10^{6}$ cells/L; $P<0.001$ placebo vs ponesimod). Interestingly, no significant differences were observed when analyzing the percentage change from baseline in TCM cells between the treatments (Figure 4C). Similarly, although a trend was observed, the change in the number of CD8 ${ }^{+}$TEM cells was not significantly different between placebo- (from $172 \pm 94 \times 10^{6}$ cells $/ \mathrm{L}$ to $205 \pm 74 \times 10^{6} \mathrm{cells} / \mathrm{L}$ )

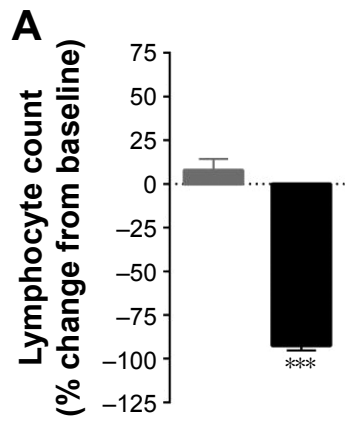

Naïve

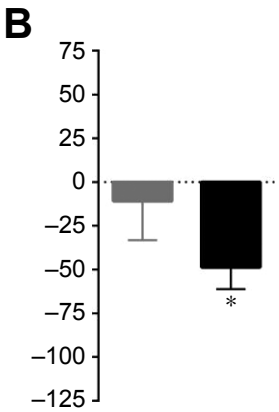

Effector
C

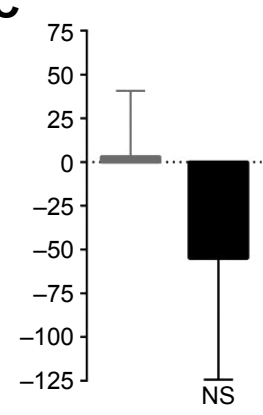

TCM

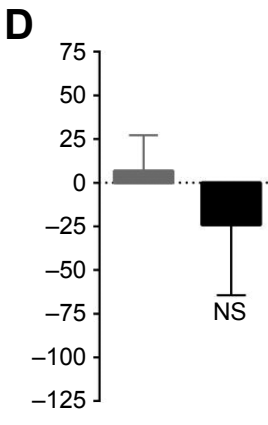

TEM

Figure 4 Effect of placebo and ponesimod on $\mathrm{CD}^{+} \mathrm{T}$ cell subsets.

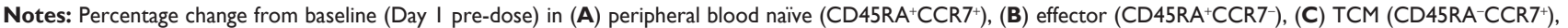
and (D) TEM (CD45RA-CCR7-) CD8 ${ }^{+}$T cells on Day 10 post-dose with placebo or ponesimod. Data are presented as mean with $S D$. Significance code: $* P<0.05$, $* * * P<0.001$; $t$-test placebo vs ponesimod.

Abbreviations: TCM, T-central memory; TEM, T-effector memory; SD, standard deviation; NS, not significant. 


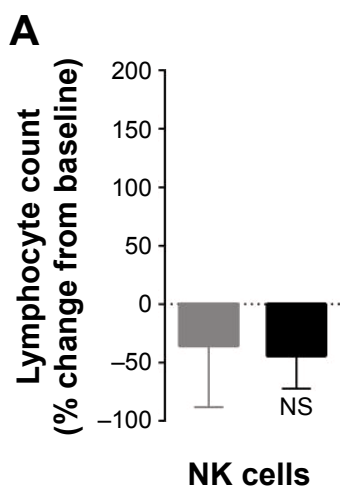

B

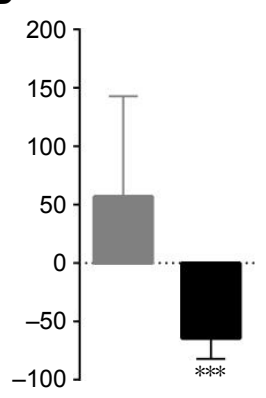

Regulatory $\mathrm{T}$ cells
C

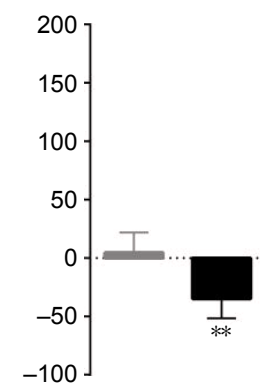

NKT cells
D

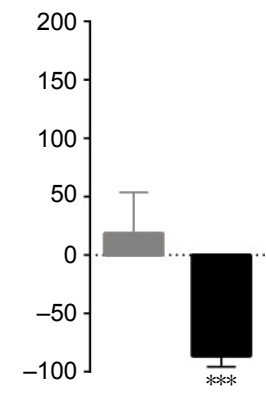

Gut-homing
E

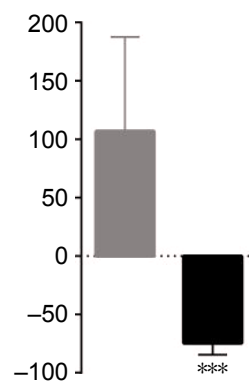

Skin-homing

Figure 5 Effect of placebo and ponesimod on NK cells, regulatory T cells, NKT cells, gut-homing T cells, and skin-homing T cells.

Notes: Percentage change from baseline (Day I pre-dose) in $(\mathbf{A})$ peripheral NK cells $\left(C D 3^{-} \mathrm{CD} 56^{+}\right),(\mathbf{B})$ regulatory $\mathrm{T}^{-}$cells $\left(\mathrm{CD} 25^{+} \mathrm{Foxp} 3^{+}\right),(\mathbf{C}) \mathrm{NKT}$ cells $\left(\mathrm{CD} 3^{+} \mathrm{CD} 56^{+}\right)$, (D) gut-homing (CLA-integrin $\left.\beta 7^{+}\right)$, and (E) skin-homing (CLA ${ }^{+}$integrin $\left.\beta 7^{-}\right) \mathrm{T}$ cells on Day 10 post-dose with placebo or ponesimod. Data are presented as mean with SD. Significance code: $* * P<0.01$, $* * * P<0.00 I$; $t$-test placebo vs ponesimod.

Abbreviations: NK, natural killer; NKT, natural killer T memory; SD, standard deviation; NS, not significant.

and ponesimod-treated subjects (from $151 \pm 68 \times 10^{6}$ cells/L to $98 \pm 43 \times 10^{6}$ cells/L; Figure $\left.4 \mathrm{D}\right)$.

\section{Effects on NK cells}

The absolute number of NK cells $\left(\mathrm{CD}^{-}{ }^{-} \mathrm{CD} 56^{+}\right)$was higher at baseline $\left(211 \pm 109 \times 10^{6}\right.$ cells $/ \mathrm{L}$ and $268 \pm 65 \times 10^{6} \mathrm{cells} / \mathrm{L}$ in the placebo and ponesimod groups, respectively) than after placebo $\left(142 \pm 81 \times 10^{6}\right.$ cells $\left./ \mathrm{L} ; P>0.05\right)$ or ponesimod $\left(100 \pm 35 \times 10^{6}\right.$ cells $\left./ L ; P<0.05\right)$ dosing. Comparison of percentage change from baseline revealed a similar decrease in placebo- $(-44 \% \pm 28 \%)$ and ponesimod-treated subjects $(-36 \% \pm 53 \% ; P>0.05$ placebo vs ponesimod; Figure $5 \mathrm{~A})$.

\section{Effects on regulatory T cells, NKT cells, gut-homing $T$ cells, and skin-homing T cells}

The number of regulatory $\mathrm{T}$ cells $\left(\mathrm{CD} 25^{+} \mathrm{Foxp} 3^{+}\right)$increased from $15 \pm 9 \times 10^{6}$ cells/L to $23 \pm 20 \times 10^{6}$ cells/L following treatment with placebo but decreased (from $12 \pm 6 \times 10^{6}$ cells $/ \mathrm{L}$ to $5 \pm 3 \times 10^{6}$ cells $/ \mathrm{L} ; P>0.05$ baseline vs Day 10 ) following o.d. administration of ponesimod for 10 days. A significant difference between placebo and ponesimod treatment on Day 10 was observed $(P<0.001$; Figure 5B), although a large variability was observed in both groups.

Although analysis of the absolute number of NKT cells $\left(\mathrm{CD}{ }^{+} \mathrm{CD} 56^{+}\right)$revealed that neither placebo nor ponesimod affected NKT cells count $(P>0.05$, baseline vs Day 10 for both), comparison of percentage change from baseline revealed a statistically significant difference between placebo and ponesimod treatment $(P<0.001$; Figure 5C).

Mean count of gut-homing T cells (CLA-integrin $\beta 7^{+}$) was significantly decreased after 10 days of ponesimod treatment (from $258 \pm 80 \times 10^{6}$ cells $/ \mathrm{L}$ to $32 \pm 17 \times 10^{6}$ cells $/ \mathrm{L}$; $P<0.001$ ), whereas there was no placebo effect (from $267 \pm 114 \times 10^{6} \mathrm{cells} / \mathrm{L}$ to $364 \pm 186 \times 10^{6}$ cells $/ \mathrm{L} ; P>0.05$ ). On Day 10, the number of gut-homing $\mathrm{T}$ cells was significantly lower in ponesimod- when compared to placebo-treated subjects $(P<0.001$; Figure 5D). The number of skinhoming $\mathrm{T}$ cells $\left(\mathrm{CLA}^{+}\right.$integrin $\left.\beta 7^{-}\right)$increased following placebo (from $26 \pm 22 \times 10^{6}$ cells $/ \mathrm{L}$ to $36 \pm 39 \times 10^{6}$ cells/L) but markedly decreased after treatment with ponesimod (from $33 \pm 15 \times 10^{6}$ cells $/ \mathrm{L}$ to $7 \pm 3 \times 10^{6}$ cells $\left./ \mathrm{L} ; P<0.01\right)$. Using percentage change from baseline, the change from baseline was significantly different between placebo and ponesimod treatment $(P<0.001$; Figure 5E).

\section{Discussion}

In this study, the effects of multiple-dose administration of ponesimod, a selective $\mathrm{S}_{1} \mathrm{P}_{1}$ receptor modulator, on lymphocyte subsets were investigated. In a previous study, we showed that single-dose administration of ponesimod leads to a higher reduction of naïve $\mathrm{T}$ cells and $\mathrm{CD} 4^{+} \mathrm{T}$ cells compared to memory $\mathrm{T}$ cells and $\mathrm{CD} 8^{+} \mathrm{T}$ cells. ${ }^{10}$ The pharmacokinetics and safety and tolerability of the up-titration regimen employed in this study have been published previously ${ }^{13}$ and revealed that on Day 10, when blood was sampled to further decipher the effects on lymphocyte subpopulations, the concentration of ponesimod in plasma was virtually at steady state.

The homeostasis of the immune system and outcome of inflammatory reactions depend on the compartmentalization of lymphocyte subsets and their ability to differentiate into pro-inflammatory and regulatory cells. The action of S1 $\mathrm{P}_{1}$ receptor modulators impedes the homing of these cells to 
sites of inflammation and alters the delicate balance between lymphocyte retention and egress.

In this study, retention of CD4 ${ }^{+}$cells was more prominent compared to $\mathrm{CD}^{+}$cells. This is in agreement with previous studies with single-dose administration of ponesimod ${ }^{10}$ and fingolimod. ${ }^{16}$ This might be related to the recruitment and priming of $\mathrm{CD}^{+}$cells that may occur in non-lymphoid organs. ${ }^{17}$

In addition to their immunological properties (eg, homing capacity or effector function), memory $\mathrm{T}$ cells can be differentiated using the expression of two markers: CD45RA and CCR7. ${ }^{12}$ It has been shown that the expression of these markers and the number of cells in each phenotype remain fairly stable in the same individual but phenotypic distribution varies considerably between individuals. ${ }^{18}$ This variation is most notable in the $\mathrm{CD}^{+}$lymphocyte subsets and could help to explain the large variation in the expression of these markers observed in the placebo group.

It is known that chemokine receptor CCR7 is necessary for lymph node homing leading to the retention of $\mathrm{CCR} 7^{+}$ cells (TCM and naïve cells) in secondary lymphoid organs. ${ }^{17}$ TEM cells that do not express CCR7 are thought to migrate directly into target tissues where they can act as effector immune cells. In addition, an increase in the $\mathrm{S}_{1} \mathrm{P}_{1}$ receptor expression could influence the conversion of naïve $\mathrm{T}$ cells into effector and effector memory cells (CD45RA-) by downregulation of CCR7. ${ }^{4}$ In addition, $\mathrm{S}_{1} \mathrm{P}_{1}$ receptor expression is high in naïve T cells and low in effector and memory cells. ${ }^{19}$ Taken together, this fully supports the present data and is in agreement with previous studies with fingolimod ${ }^{16}$ in which naïve T cells and TCM cells are more affected by selective and non-selective S1P receptor modulators compared to TEM cells and effector $T$ cells that both continue to reside outside secondary lymphoid tissues. Although ponesimod effects on $\mathrm{T}$ cell subpopulations reported in this study follow these general principles, as illustrated by the selective sparing of the CD8 $8^{+}$TEM cells, it is important to note that ponesimod treatment results in a distinct, significant decrease in $\mathrm{CD}^{+}$TEM cells. This differential effect on $\mathrm{CD}^{+} \mathrm{TEM}$ challenges the assumption that $\mathrm{CD}^{+}$and $\mathrm{CD} 8^{+} \mathrm{TEM}$ cells share similar migration mechanisms. Indeed, a recent study on the distribution of the human $\mathrm{T}$ cell subpopulations has reported that $\mathrm{CD}^{+} \mathrm{TEM}$ cells are primarily resting and compartmentalized, whereas $\mathrm{CD} 8^{+}$TEM cells show increased circulation through tissues. ${ }^{20}$ Furthermore, the lack of CCR7 expression did not result in the exclusion of $\mathrm{T}$ cells from lymphoid organs, as $20 \%-50 \%$ of the total $\mathrm{T}$ cells found in human lymph nodes were $\mathrm{CCR}^{-}{ }^{-} \mathrm{TEM}$ cells. Thus, $\mathrm{CD}^{+}$ TEM cells despite being CCR7 ${ }^{-}$may enter the lymph nodes and their exit could be prevented by ponesimod. Indeed, a recent study in a mouse model has confirmed that the entry of CD4 ${ }^{+}$TEM cells into lymph nodes is independent of CCR7 expression. ${ }^{21}$ Therefore, ponesimod treatment could reduce the number of CD4+ TEM cells in the blood, as these cells appear to be able to enter lymph nodes despite the lack of CCR7 expression and may require $\mathrm{S}_{1} \mathrm{P}_{1}$ receptor signal to exit into the circulation.

Nevertheless, the mechanisms that could explain the lack of similar effects on CD4+ TEM cells by non-selective S1P receptor modulators such as fingolimod remain to be clarified. The differential effects between ponesimod and fingolimod are likely due to the binding of the latter to $\mathrm{S}_{1} \mathrm{P}_{3-5}$ receptors. As $\mathrm{S}_{1} \mathrm{P}_{4}$ is expressed on immune cells, it is feasible that fingolimod binding to $\mathrm{S}_{1} \mathrm{P}_{4}$ could modulate $\mathrm{S} 1 \mathrm{P}_{1}$ signaling ${ }^{22}$ or may act indirectly by affecting $\mathrm{T}$ cell interaction with dendritic cells. ${ }^{23}$

Calculation of absolute numbers of $\mathrm{T}$ regulatory cells $\left(\mathrm{CD} 25^{+} \mathrm{Foxp}^{+}\right)$demonstrated a moderate non-significant decrease in the number of these cells circulating during ponesimod treatment. A study in chronic plaque psoriasis patients revealed that the effect of ponesimod on $\mathrm{CD}^{+} \mathrm{T}$ regulatory cells is low relative to the effect on conventional $\mathrm{CD}^{+}$ T cells. ${ }^{9}$ Interestingly, a recent clinical study showed that MS patients have a decreased number of $\mathrm{T}$ regulatory cells and that fingolimod did not significantly change $\mathrm{T}$ regulatory cells count in MS patients. ${ }^{24} \mathrm{NKT}$ cells $\left(\mathrm{CD} 3{ }^{+} \mathrm{CD} 56^{+}\right)$do not require $\mathrm{S}_{1} \mathrm{P}_{1}$ receptor expression for development in the thymus, but the receptor is necessary for these cells to emerge into peripheral tissues. Once established, $\mathrm{S}_{1} \mathrm{P}_{1}$ receptor expression does not appear to alter the distribution of these cells. ${ }^{25}$ This observation is supported by data in a mouse model in which fingolimod did not alter the distribution of NKT cells within peripheral tissues. ${ }^{26}$ The absolute number of NKT cells on Day 10 was similar in the active and placebo groups, suggesting that these cells are largely unaffected by ponesimod. This could in part be due to the low rate of entry of NKT cells into lymph nodes due to their low expression of CCR7 and CD62L. ${ }^{25}$ Although NKT cells are a variable population with low numbers in peripheral blood, rendering their analysis difficult, the data in this study support previous observations in animal studies that absolute numbers or tissue distribution of NKT cells are largely unaffected by administration of an $\mathrm{S}_{1} \mathrm{P}_{1}$ receptor modulator. ${ }^{26}$

The effects of ponesimod on $\mathrm{T}$ cell subsets show considerable overlap with the effects of the non-selective S1P receptor modulator fingolimod. However, our data provide clear evidence that the effects of ponesimod on $\mathrm{T}$ cell subsets are complex with distinct effects on $\mathrm{CD}^{+}$and $\mathrm{CD}^{+} \mathrm{T}$ cells 
that do not conform to the mode of action of fingolimod. Here, we report that in contrast to fingolimod, ${ }^{27}$ ponesimod treatment results in a significant reduction in $\mathrm{CD}^{+} \mathrm{TEM}$ cells. This effect could be important in MS and other autoimmune diseases, as CD4+ ${ }^{+}$TEM cells potentially contribute to immunopathology. ${ }^{28,29}$

\section{Acknowledgment}

Actelion Pharmaceuticals Ltd provided funding for this clinical trial.

\section{Author contributions}

All authors contributed toward data analysis, drafting and critically revising the paper and agree to be accountable for all aspects of the work.

\section{Disclosure}

Pierre-Eric Juif, Daniele D’Ambrosio, and Jasper Dingemanse are full time employees of Actelion Pharmaceuticals Ltd. The other authors report no conflicts of interest in this work.

\section{References}

1. von Andrian UH, Mackay CR. T-cell function and migration. Two sides of the same coin. N Engl J Med. 2000;343(14):1020-1034.

2. Brinkmann V. Sphingosine 1-phosphate receptors in health and disease: mechanistic insights from gene deletion studies and reverse pharmacology. Pharmacol Ther. 2007;115(1):84-105.

3. Cyster JG. Chemokines, sphingosine-1-phosphate, and cell migration in secondary lymphoid organs. Annu Rev Immunol. 2005;23:127-159.

4. Schwab SR, Cyster JG. Finding a way out: lymphocyte egress from lymphoid organs. Nat Immunol. 2007;8(12):1295-1301.

5. Schwab SR, Pereira JP, Matloubian M, Xu Y, Huang Y, Cyster JG. Lymphocyte sequestration through S1P lyase inhibition and disruption of S1P gradients. Science. 2005;309(5741):1735-1739.

6. Chiba K, Matsuyuki H, Maeda Y, Sugahara K. Role of sphingosine 1-phosphate receptor type 1 in lymphocyte egress from secondary lymphoid tissues and thymus. Cell Mol Immunol. 2006;3(1):11-19.

7. Chun J, Brinkmann V. A mechanistically novel, first oral therapy for multiple sclerosis: the development of fingolimod (FTY720, Gilenya). Discov Med. 2011;12(64):213-228.

8. Olsson T, Boster A, Fernandez O, et al. Oral ponesimod in relapsingremitting multiple sclerosis: a randomised phase II trial. J Neurol Neurosurg Psychiatry. 2014;85(11):1198-1208.

9. Vaclavkova A, Chimenti S, Arenberger P, et al. Oral ponesimod in patients with chronic plaque psoriasis: a randomised, double-blind, placebo-controlled phase 2 trial. Lancet. 2014;384(9959):2036-2045.

10. D'Ambrosio D, Steinmann J, Brossard P, Dingemanse J. Differential effects of ponesimod, a selective S1P1 receptor modulator, on blood-circulating human T cell subpopulations. Immunopharmacol Immunotoxicol. 2015;37(1):103-109.

11. Song ZY, Yamasaki R, Kawano Y, et al. Peripheral blood T cell dynamics predict relapse in multiple sclerosis patients on fingolimod. PLOS One. 2014;10(4): 0124923.
12. Sallusto F, Geginat J, Lanzavecchia A. Central memory and effector memory T cell subsets: function, generation, and maintenance. Annu Rev Immunol. 2004;22:745-763.

13. Hoch M, D'Ambrosio D, Wilbraham D, Brossard P, Dingemanse J. Clinical pharmacology of ponesimod, a selective $\mathrm{S}_{1} \mathrm{P}_{1}$ receptor modulator, after uptitration to supratherapeutic doses in healthy subjects. Eur J Pharm Sci. 2014;63C:147-153.

14. Brossard P, Scherz M, Halabi A, Maatouk H, Krause A, Dingemanse J. Multiple-dose tolerability, pharmacokinetics, and pharmacodynamics of ponesimod, an S1P1 receptor modulator: favorable impact of dose up-titration. J Clin Pharmacol. 2014;54(2):179-188.

15. Scherz MW, Brossard P, D'Ambrosio D, Ipek M, Dingemanse J. Three different up-titration regimens of ponesimod, an S1P1 receptor modulator, in healthy subjects. J Clin Pharmacol. 2015;55(6):688-697.

16. Brinkmann V, Billich A, Baumruker T, et al. Fingolimod (FTY720): discovery and development of an oral drug to treat multiple sclerosis. Nat Rev Drug Discov. 2010;9(11):883-897.

17. Lewis M, Tarlton JF, Cose S. Memory versus naive T-cell migration. Immunol Cell Biol. 2008;86(3):226-231.

18. Sallusto F, Lenig D, Forster R, Lipp M, Lanzavecchia A. Two subsets of memory $\mathrm{T}$ lymphocytes with distinct homing potentials and effector functions. Nature. 1999;401(6754):708-712.

19. Garris CS, Blaho VA, Hla T, Han MH. Sphingosine-1-phosphate receptor 1 signalling in T cells: trafficking and beyond. Immunology. 2014; 142(3):347-353.

20. Thome JJ, Yudanin N, Ohmura Y, et al. Spatial map of human T cell compartmentalization and maintenance over decades of life. Cell. 2014; 159(4):814-828.

21. Vander Lugt B, Tubo NJ, Nizza ST, et al. CCR7 plays no appreciable role in trafficking of central memory CD4 T cells to lymph nodes. J Immunol. 2013;191(6):3119-3127.

22. Sic H, Kraus H, Madl J, et al. Sphingosine-1-phosphate receptors control B-cell migration through signaling components associated with primary immunodeficiencies, chronic lymphocytic leukemia, and multiple sclerosis. J Allergy Clin Immunol. 2014;134(2):420-428.

23. Schulze T, Golfier S, Tabeling C, et al. Sphingosine-1-phospate receptor $4(\mathrm{~S} 1 \mathrm{P}(4))$ deficiency profoundly affects dendritic cell function and TH17-cell differentiation in a murine model. FASEB J. 2011;25(11): 4024-4036.

24. Venken K, Hellings N, Broekmans T, Hensen K, Rummens JL, Stinissen $P$. Natural naive CD4+CD25+CD127low regulatory T cell (Treg) development and function are disturbed in multiple sclerosis patients: recovery of memory Treg homeostasis during disease progression. J Immunol. 2008;180(9):6411-6420.

25. Allende ML, Zhou D, Kalkofen DN, et al. S1P1 receptor expression regulates emergence of NKT cells in peripheral tissues. FASEB J. 2008; 22(1):307-315.

26. Hwang SJ, Kim JH, Kim HY, Kim S, Chung DH. FTY720, a sphingosine 1-phosphate receptor modulator, inhibits CD1d-restricted NKT cells by suppressing cytokine production but not migration. Lab Invest. 2010;90(1):9-19.

27. Nishihara H, Shimizu F, Sano Y, et al. Fingolimod prevents bloodbrain barrier disruption induced by the sera from patients with multiple sclerosis. PLoS One. 2015;10(3):e0121488.

28. Kamanaka M, Huber S, Zenewicz LA, et al. Memory/effector (CD45RB(lo)) CD4 T cells are controlled directly by IL-10 and cause IL-22-dependent intestinal pathology. J Exp Med. 2011;208(5): $1027-1040$

29. Jaigirdar SA, MacLeod MK. Development and function of protective and pathologic memory CD4 T cells. Front Immunol. 2015;6:456. 


\section{Supplementary material}

A
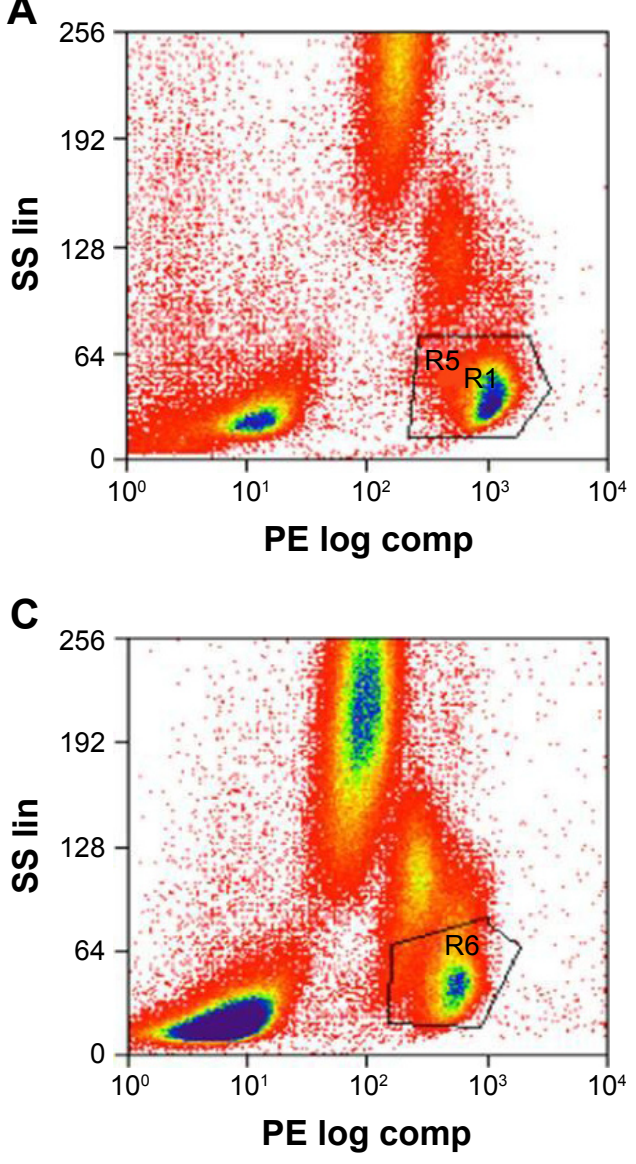

B

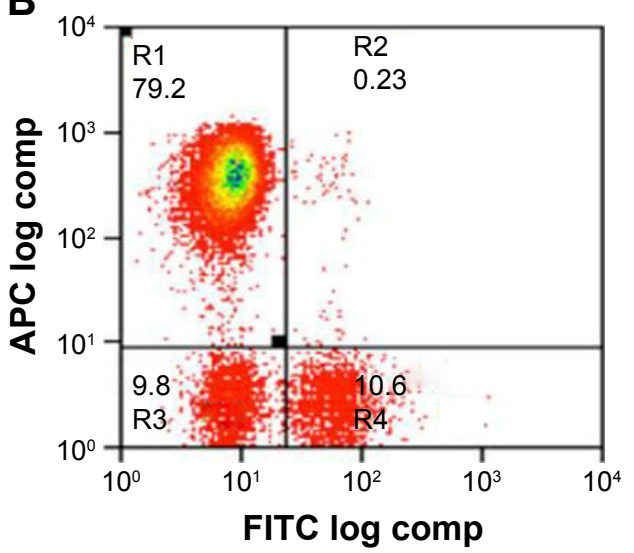

D

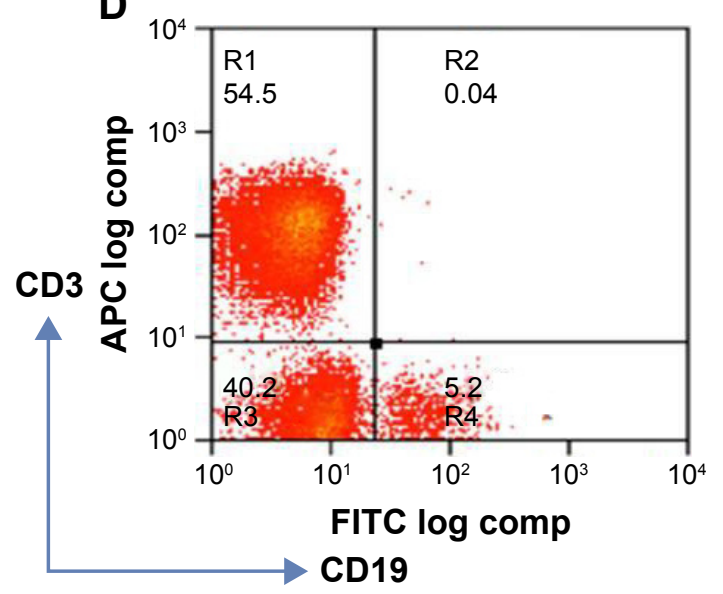

Figure SI Flow cytometry graphs showing reduction in the percentages of T and B cells after multiple-dose administration of ponesimod (Day I0).

Notes: (A) Baseline dot plot of whole blood stained with anti-CD45-PE, CD3-APC, and CDI9-FITC. CD45+ lymphocytes were gated (RI) using a CD45-PE/SSC plot. (B) CDI9-FITC/CD3-APC plot was generated when gated on RI. The percentage (\%) of CDI9+ B cells is shown in lower right quadrant and \% CD3 ${ }^{+} \mathrm{T}_{\text {cells in }}$ the upper left quadrant. (C) Day 10 dot plot of whole blood similarly stained. Flow cytometry profile shown is from a representative ponesimod-treated subject. (D) CDI9-FITC/ CD3-APC plot was generated when gated on R6.

Abbreviations: PE, phycoerythrin; APC, allophycocyanin; FITC, fluorescein isothiocyanate; SSC, side scatter; lin, linear; log, logarithmic.

\section{Publish your work in this journal}

Drug Design, Development and Therapy is an international, peerreviewed open-access journal that spans the spectrum of drug design and development through to clinical applications. Clinical outcomes, patient safety, and programs for the development and effective, safe, and sustained use of medicines are the features of the journal, which has also been accepted for indexing on PubMed Central. The manuscript management system is completely online and includes a very quick and fair peer-review system, which is all easy to use. Visit http://www.dovepress.com/testimonials.php to read real quotes from published authors. 